Article

\title{
What Do We Know? Lessons from the History of Race Relations within Constabularies
}

\author{
Simon Holdaway*
}

Abstract During the 1980s and 1990s a great deal of work was undertaken by constabularies wanting to increase the number of Black and minority ethnic (BME) officers in their ranks. Academic research about this and a number of related subjects was published, informing Home Office policy communicated to chief officers. Many BME officers joined Black and other minority ethnic police associations, further developing policies and practices. We know a good deal about BME officers but the indications are that the police have learned little from the considerable knowledge available. This article explores lessons learned from the research about BME officers and considers their neglect within constabularies.

\section{Introduction}

The College of Policing, the police professional body, is currently engaged in a special project,
BME Progression 2018, to address the lack of Black and ethnic minority (BME) applicants and recruits into the constabularies of England and Wales; the small number of BME officers in the promoted ranks; and the problem of their premature resignation (College of Policing, 2013). Substantial academic research about these subjects has been published and informed national policies for over two decades. This work has described and analysed recruitment processes as they affect BME applicants (Holdaway, 1991; Stone and Tuffin, 2000); the path of personal decision-making that leads to resignation from a constabulary (Holdaway and Barron, 1997); the work experiences of serving BME officers, especially relationships with ethnic majority colleagues (Holdaway, 1997a,b; Cashmore, 2001, 2002); and the organization of Black Police Associations (BPAs), not least as a social movement within the police (Holdaway, 2004, 2009; Phillips, 2005). There are significant gaps in the research, of course, BME career progression being one (Mundy et al., 1999). We nevertheless know quite a lot from published research about the worlds of BME police applicants, serving officers, and resigners.

Major findings from this corpus of research and their lessons for policy are identified in this article. First, key research findings from relevant studies are outlined and their implications for the current situation within which BME Progress 2018 is

*Simon Holdaway, Professor of Criminology, Nottingham Trent University, Professor Emeritus of Criminology and Sociology, Sheffield University. E-mail: s.holdaway@ntu.ac.uk

Policing, pp. 1-10

doi:10.1093/police/pau053

(C) The Author 2015. Published by Oxford University Press. All rights reserved.

For permissions please e-mail: journals.permissions@oup.com 
developing are discussed. Attention is then given to the recruitment and retention of BME officers. These are related matters, concerned with race relations within and out with constabularies. ${ }^{1}$ The development and functions of BPAs are considered next. Particular attention is paid to how BPAs have influenced a change in the occupational identity of BME officers. The notion of an institutional memory' of racism within constabularies is explored briefly. Before conclusions from these subjects are drawn the fundamental rationale for placing an emphasis on BME police recruitment is considered. It is argued that racial justice and fairness are more appropriate foundations for BME recruitment than ideas associated with the English and Welsh police workforce representing the national or local population.

\section{Recruitment and retention}

During the late 1980s and throughout the 1990s, constabularies in England and Wales developed initiatives to recruit police officers from BME groups routinely (Wilson et al., 1984; Holdaway, 1991). Many were innovative and included opportunities for officers to talk directly to Black and Asian British people who ordinarily would not have encountered the police. Police recruitment caravans, for example, were parked in town centres, attracting attention from potential applicants and, importantly, providing opportunities for people from BME groups to talk to officers, assessing their attitudes and approach to policing before deciding whether to apply for appointment to a constabulary. Many other recruitment initiatives brought police and people together in novel ways.

As part of research about recruitment, serving BME officers were interviewed about their experiences of police employment (Holdaway, 1991, op. cit.). They described a context of police work in which white colleagues subjected them to frequent, open racial prejudice, and discrimination. BME officers adjusted to and in some cases rationalized this situation in different ways but if potential recruits heard about it they would hardly be encouraged to join a constabulary (Holdaway, 1997a,b). Data from separate interviews indicated clearly that supervisory officers of all ranks were unaware of the experience of their BME colleagues and took no action to prevent racial prejudice or discrimination. In addition to questions about work conditions, pay, and the status of police employment, BME applicants had to consider their minority status within a constabulary and, if appointed, ethnic majority colleagues' racially prejudicial attitudes and discriminatory actions.

When asked about how they decided on a police career, serving BME officers described an often lengthy process of reflection based on information from a range of people. Family members, friends, acquaintances, serving police officers, and others were asked for their opinions about a police career. The possibility of racial prejudice and discrimination within the workforce and racially discriminatory policing of BME groups were central to these conversations.

Having supported and encouraged wide-spread recruitment work, the Home Office (1990) realized that the number of BME officers resigning from constabularies seemed to be needlessly high and research about the subject was commissioned (Holdaway and Barron, 1997). ${ }^{2}$ In this research, interviews about the reasons for a decision to leave police employment and the process of discernment that led to it were held with a sample of Black and Asian resigners from a number of constabularies. Consistent with findings from Holdaway's research about recruitment, overt racial prejudice, and discrimination, supervisory and managerial ranks' ignorance of Black and

\footnotetext{
${ }^{1}$ When I refer to 'race relations' I am concerned with a social construction not a physiological, biological categorization of a person Sansone, L. (2003). Blackness Without Ethnicity. Basingstoke, Palgrave Macmillan.

${ }^{2}$ It is interesting to recall that robust statistics of resignations were not available at the time.
} 
Asian officers' experiences and the absence of a framework of strategy to link recruitment and resignation, including consideration of work relationships between BME and white officers, were central features of an explanation of why many BME officers resigned from the police service.

It was found that there was no single point at which officers decided to resign. Rather, resignation was the end point of a long process within which

\footnotetext{
${ }^{3}$ The figures quoted are of the proportion of ethnic minority officers within the workforce. They are complex and only portray a rough grained representation of BME recruitment and retention. Officers resign and leave police employment for a host of reasons. The extent of recruitment opportunities changes within and over the years. The proportion within different constabularies differs greatly, absolutely, and across time.

${ }^{4}$ This is explained by the recent use by constabularies of a regulation allowing them to require officers with 30 years pensionable service to retire. BME officers are less likely to come within the 30 year qualifying period.

${ }^{5}$ These figures are relevant if BME representation in the police is to reflect BME representation in the national population. The age profile, career choices, educational qualifications, and many other variables are also important when the employable percentage of BME populations is considered.
} 


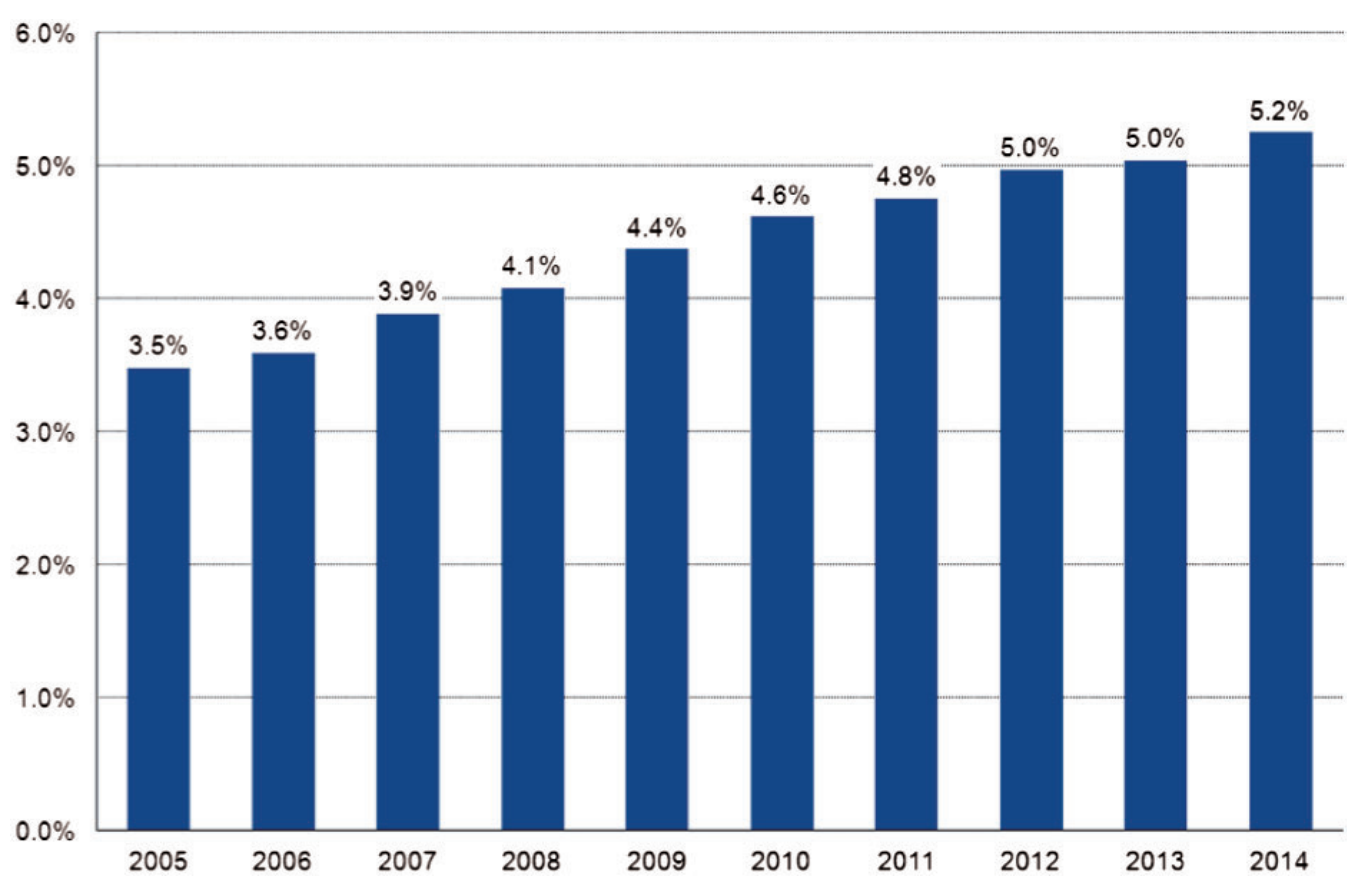

Chart 1. Proportion of officers who are Minority Ethnic, as at 31 March 2005 to 2014, UK. ${ }^{6}$ Source: Home Office, Police workforce, UK, 31 March 2014.

linking race relations within and out-with constabulary is adequate.

\section{Black Police Associations and changing identities}

Familiarity with prejudice and discrimination at work led officers in a number of constabularies to group together and form BPAs (Holdaway, 2009). A substantial number of BME officers demonstrated their resistance to chief officers' ignorance and neglect of race relations within constabularies. By forming BPAs, they strengthened and displayed publicly black police officers' collective identity; challenged white colleagues' negative stereotypes and discrimination; and required a constructive response from chief officers
(Holdaway, 2004). Within this context, race relations developed a higher profile within forces; chief officers held regular meetings with BPA chairs and reserved places for them at policy committee tables; BME officers had a formally recognized body to support them, and the ethnic identities of BME officers became more central to their police work.

A key dimension of the experiences of BME officers is a repositioning of their identities. For many, in just a decade, their occupational identity has changed from 'police officer who happens to be Black' to 'Black police officer' (Holdaway, 2004). ${ }^{7}$ Ethnicity is a self-designation, related to race categorizations by others (Jenkins, 1996, 1997). We define ourselves as 'Black', 'White', 'Asian', 'African', and so on. Others categorize us, maybe

\footnotetext{
${ }^{6}$ Based on full-time equivalent figures for the 43 forces of UK only.

7 This study was based on interviews with the Presidents and Secretaries of all 39 BPAs in England and Wales and with chief police officers with responsibility for them in their constabularies.
} 
differently or in different social contexts, in similar or dissimilar ways (Sansone, 2003).

In Holdaway's research about recruitment, officers described themselves as 'police officers who happen to be black' (Holdaway, 1991, op. cit.). The momentum generated by BPAs was, as their name suggests, organized around the category 'black'. Many Asian officers were content to accept that their experience of police employment was, like that of their Afro-Caribbean and African background colleagues, one of racial prejudice and discrimination and therefore essentially the same. They defined themselves as 'black'. Others did not, regarding themselves as 'Asian' or in some cases 'Muslim' or 'Hindu'. A small number of other associations developed to represent ethnic groups that could not cohere around this categorization. Their focus was as much and at times more upon cultural differences than race prejudice and discrimination. ${ }^{8}$ The key point is this: in the early 90s, BME officers did not place being Black or Asian as central to their occupational identity (Holdaway, 1991, op. cit.). Within the context of day-to-day police employment, however, their white colleagues persisted with their categorization as Black people, which was to have important effects.

First in the Metropolitan Police and subsequently in many other constabularies, BPAs developed to place the category of 'Black police officer' in the ascendancy and to organize around it at work (Holdaway, 2009). It is difficult to identify another major change in constabularies that has begun from the organization of the lower ranks. BPAs organized to communicate a clear view that their experience of being a police officer was different from that of a white officer; that special attention should be given to the racial prejudice and discrimination they face; that they, not white offi- listened to as a distinct group within the police workforce.

Many chief constables responded to this situation by providing BPA officials with seats at policy committee tables and an open door to their offices. BPAs gave officers an opportunity to develop support and mentoring programmes. A capacity to initiate grievances and employment tribunal cases became evident and, importantly, a conduit from race relations within to those outwith constabularies was established. BPAs' priority was to address race relations within constabularies, preparing the ground for a possible increase in recruitment sometime in the future. Once recruited, many BME officers would join their ethnic peers who countered negative connotations of their being Black.

BPAs changed the topography of race and ethnicity in policing. As they emerged in most English and Welsh constabularies, BME officers' confidence grew, chief officers had a formal link with BME staff, and a sounding board for their views. Grievances about treatment at work were afforded a firm basis of support by colleagues. Crucially, BPAs began to address race relations within and out-with constabularies.

Some BPAs, not least their National BPA, made some unfortunate mistakes and damaged their credibility (BBC News, 2014). Home Office enthusiasm for the National Association weakened, understandably. The impetus was lost about 5 or so years ago, coinciding with the neglect of all BME matters, an important topic to which we will return later.

BPAs have nevertheless demonstrated ways in which BME officers have led the way to reform race relations within constabularies and are a key resource for chief officers addressing ethnic inequalities within constabularies. The research evidence points towards the importance of BPAs and

\footnotetext{
${ }^{8}$ Most of these groups were found in the Metropolitan Police Service, the Muslim, Hindu, Sikh, Jewish, and Cypriot police associations, for example.
} 
other ethnic minority police associations in recruitment, retention and, crucially, policies concerned with relations within and out with constabularies.

\section{Institutional memory}

There is a further important aspect to BPA's work, which is enduring. The point appears to be a simple one but it is fundamental and difficult to resolve. During national research about BPAs, Holdaway asked their chairs and secretaries to provide examples of 'institutional racism'. It was striking that they often drew on examples that affected them as an individual rather than describing matters pertinent to an understanding of the police as an institution. Further, the incidents often occurred some years in the past. The present state of race relations within their constabulary was an aspect of a continuing history of race relations within the police. A vivid memory of racism, shared with ethnic peers, formed an enduring, institutional memory of racism (Holdaway, 2009, op. cit. pp. 77-81. Also see, for example, Boesen et al., 2012).

A number of relevant data about police approaches to race relations have received publicity during the last 12 months. The Metropolitan Police Service revealed that it shredded documents related to the Lawrence Report (Wright, 2014). A BME officer from the same force won a nationally reported industrial tribunal case in which race discrimination was alleged; references to race discrimination had been edited from key papers (Williams, 2014). Cleveland's chief constable referred allegations of discrimination by her force BPA to the Independent Police Complaints Authority (Hetherington, 2014). Greater Manchester Police's sanctions against their BME officers subject to investigation for internal disciplinary offences have been found discriminatory (Smith, 2012). A number of chief constables advocate positive discrimination to recruit BME officers while not also recognizing the views of $\mathrm{BME}$ officers who are opposed to it and internal problems of race relations within their constabularies. All of these incidents, and more, sustain an institutional memory of racism in the police service.

This is not to argue that reform faces inevitable failure: far from it. It is to argue that chief and supervisory officers need to understand the present impact of historic race prejudice and discrimination and be sensitive to it. It means positive action when making decisions - a double and triple checking for any prejudice and, or discrimination and doing so on the basis that many past decisions have affected BME officers unfavourably. And it brings us back to a need for long-term strategic rather than short-term project-based change.

\section{Representation and racial justice}

Note that the notions of 'culture' and 'multiculturalism' have not yet been used in this article. That is intentional because the institutional memory to which I refer is about racial justice and fairness rather than cultural diversity and responding to it by the provision, for example, of appropriate food in canteens, the availability of prayer rooms and related measures. The recognition of cultural differences and accommodating to them with appropriate policies is important. There is no doubt about that but the rationale for the recruitment, retention, or any other policy concerned with BME officers is more concerned with racial justice than with 'representing the population policed' or fostering ethnic diversity within the police.

The Deputy Mayor for Policing in London announced recently that recruitment to the Metropolitan Police is now limited to candidates who have lived in London for a defined period (London Gov UK http://tinyurl.com/mkt2dqq). It is necessary for the Metropolitan Police to 'look like London'. Other force representatives have argued in a similar vein, restricting recruitment to local applicants. This takes us to a fundamental question about BME recruitment-'Why do it?' 
There is a lack of clarity within the UK police about why BME recruitment and associated work is undertaken. This matters because different understandings lead to different policies. Put too simply and briefly, if the rationale is to reflect the ethnic make-up of the population policed, a constabulary will find itself chasing demographic changes. Some forces, for example, will need to recruit from their East European populations, presumably in proportion to their representation in the local population. Some London boroughs have populations with over 100 ethnic groups. $42 \%$ of Londoners ( 4 out of 10) identify themselves as other than White British (Office of National Statistics, http://tinyurl.com/nbc7w67). Global movements of people mean that this demographic pattern changes, almost constantly, with police recruitment policy based on 'reflection' trying to catch-up.

The ethnic composition of the national population is changing, perhaps more extensively than is realized. Categories 'black' and 'white" as descriptors of ethnic ascriptions might become less adequate. The Indian (1,412,598), Pakistani $(1,124,511)$, and Black African $(989,628)$ populations are considerably larger than the Black Caribbean population (594,825) (The Policy Exchange, 2014). The Black African group is the fastest growing ethnic group. White and Black Caribbean groups are the slowest growing. People of mixed ethnicity, however, now form the second largest minority population and are the fastest growing. Between 2002 and 2011 that group grew by $85.2 \%$.

Census categories do not tell us a great deal about people's identities, which to some extent are related to the social contexts within which they are articulated (Barth, 1969). When stopped by police, for example, a black youth may identify more clearly as 'black' rather than 'Black British' or some such. We therefore have to be cautious when working with quantitative demographic data about personal and occupational identities. The 2011 Census, however, included questions about ethnic identity and, apart from Black Africans (59\%), large proportions of all other ethnic groups reported a form of UK identity. $88 \%$ of Black Caribbean's, for example, included an aspect of UK identity when asked to define their identities. That figure compares with $75 \%$ of Indians and 59\% of Black Africans answering the same question (Office of National Statistics, Ethnicity, and Identity in UK 2011 http://tinyurl. com/cudf6e3).

Further, police policies based on ethnicity identify with cultural differences between groups, characterized by officers' life styles and, significantly, religious beliefs. Related policies address difference rather than shared ethnic characteristics. The emphasis is on BME officers' claims to cultural difference when compared with 'White' officers.

Policies to meet claims to cultural difference are needed but differ from those based on 'racial justice'. Here, a universal claim to justice and fairness is given priority over cultural distinctions (Manning, 2011). Sameness rather than difference should be the keynote of policy with, for example, the eradication of racial prejudice and, or discrimination from workforce relationships, the equitable use of police resources and of police powers like stop and search, and the fair use of selection processes brought to the fore. ${ }^{9}$ These are matters drawing the majority of complaints from BME officers and the population more generally. They are subjects concerned with justice, fairness, and sameness rather than accommodation to differences between groups.

\section{Conclusions}

A question from a member of the audience at the House of Commons Home Affairs Select Committee conference on 'Police Standards and

\footnotetext{
${ }^{9}$ The research literature about legitimacy in criminal justice may be very relevant to BME understandings of recruitment and disciplinary processes. See, for example, Bradford et al. (2014).
} 
Leadership' rather than police analysis of research or other data sparked current police interest in BME officers (House of Commons: Home Affairs Select Committee, 2013). Asked about the ethnic representativeness of chief officer ranks, Hugh Orde, President of the Association of Chief Police Officers, expressed concern about the very small number of BME officers holding chief officer rank. The House of Commons

Home Affairs Committee probed this subject as part of their inquiry into police leadership and standards (House of Commons: Home Affairs Select Committee, 2013). Typically, a sizeable police project was set-up quickly-'BME Progression 2018' - to inquire into BME recruitment, retention, and progression through the ranks. A report is due in autumn 2015 (College of Policing, 2014).

'BME Progression 2018' is telling. Considerable attention was given to BME recruitment, retention, and related matters during the late 1990s and the years following the publication of the Lawrence Report (Sir William Macpherson of Cluny, 1999). Interest in these subjects then waned. It seems that whatever constabularies learned about the recruitment and retention of BME officers has not been placed within long-term strategy. Less was learned about the progression of BME officers, partly because a small number of them had served sufficient years to consider promotion. We know a good deal about what works best in the areas of BME recruitment, retention, and support but the establishment of BME Progress 2018 tells us that these subjects have been neglected after a period of concerted police action to address them during the 1990s and first years of the following decade. It seems that chief officers thought they had dealt with BME issues once they responded to the Lawrence Report. Their understanding of the time scale and implementation of management led them on, quickly, to the next contemporary subject for action. Resources were available to chief officers to continue work on BME issues but they chose to neglect them, which has led to the current situation.
Finally, policies and practices addressing BME officers inform us clearly that work within constabularies must be considered within the wider context of relationships with BME communities. Evidence from research on recruitment informs us that views about the equity and tenor of the policing of BME people are an important consideration for a potential applicant. Research about the resignation of BME officers informs us that a decision to leave a constabulary is based on a lengthy consideration of what might at times seem insignificant experiences of marginalization within the workforce. Once an officer has resigned, a similarly large circle of people that provided comment about a police career before recruitment hears about racial prejudice and discrimination within a constabulary. Race relations within constabularies are related closely to police race relations out with them.

With these points from research in mind, aspects of the policing of BME people can also reinforce negative questioning of and, maybe, the rejection of a police career. The disproportionate use of stop and search powers against BME people is an obvious topic that is highly pertinent to views about recruitment and to be placed alongside cases of discrimination in employment, the use of disproportionately stringent disciplinary powers when dealing with BME officers and other matters discussed in this article. One essential benefit of considering and acting to create greater racial justice and fairness within constabularies is the necessity to think about and create greater justice and fairness in the use of police powers generally, a more equitable allocation of resources and a strategic approach to policing.

The 'institutionalized memory of race' within constabularies is long-standing, the very opposite of the amnesia of chief officers. 'BME Progression 2018' could make an important impact if it focuses its specific recommendations on these wider subjects of justice and fairness, not least to create managerial and supervisory structures within policing that cultivate a memory of racial injustice and unfairness, and how they have been remedied. 
The statistical evidence of BME recruitment into the police demonstrates a long-term trend of slow numerical increases. It has extended across periods of greater and lesser police activity to attract and retain BME officers. Systematic research based on evidence provided by BME serving officers and resigners informs us that racially prejudicial and discriminatory incidents within the police workforce and in the policing of BME people are relevant to the trend. The requirement is a long-term strategy providing a unified framework for policy and action. Within such a strategy, action to increase recruitment and retention should figure as prominently as action to ensure stop and search powers are used justly and fairly; Black and other ethnic police associations addressing injustice within constabularies should stand alongside action to ensure trusting relationships between a constabulary and its BME populations. All aspects of race relations within constabularies and those affecting relationships between a constabulary and its BME populations should be included in the long-term strategy. This would provide chief officers and those with responsibility for police accountability to assess the extent to which all aspects of the strategy are pursued. BME Progress 2018's central task is to provide constabularies with guidance about such a crucial strategy. That is the conclusion to which the research leads.

30

\section{References}

British Society of Policing Network. (2013). 'We have done that'; Race relations within constabularies. http://tinyurl. com/pbbspgx (accessed 29 December 2014).

BBC News. (2014). Ali Dizaei appeal against conviction rejected, http://tinyurl.com/dyxqpfb (accessed 29 December 2014).

Barth, F. (ed.) (1969). Ethnic Groups and Boundaries: The Social Organisation of Cultural Difference. Boston: Little, Brown and Company.

Bradford, B., Jackson, J. and Hough, M. (2014). 'Police Futures and Legitimacy: Redefining 'good policing'.' In Brown, J. M. (ed.), The Future of Policing. London: Routledge, pp. 79-100.
Boesen, E., Lentz, F. and Margue, M. (eds) (2012). Peripheral Memories: Public and Private Forms of Experiencing and Narrating the Past. Blelefeld: Fonds Nationale de la Recherche Luxemburg.

College of Policing. (2014). 'BME Progression 2018.' http://tinyurl.com/q2cpgeb (accessed 29 December 2014).

Cashmore, E. (2001). 'The Experiences of Ethnic Minority Police Officers in Britain: Under Recruitment and Racial Profiling in a Performance Culture.' Ethnic and Racial Studies 24(4): 642-659.

Cashmore, E. (2002). 'Behind the Window Dressing: Ethnic Minority Police Perspectives on Cultural Diversity.' Journal of Ethnic and Migration Studies 28(2): 327-341.

College of Policing. (2013). 'BME Progression 2018.' http:// tinyurl.com/q2cpgeb (accessed 29 December 2014).

Hetherington, G. (2014). Complaints over institutional racism report referred to independent watchdog by Cleveland Police. http://tinyurl.com/k6xbehm (accessed 29 December 2014).

Holdaway, S. (1991). Recruiting a Multi-Racial Police Force. London: HMSO.

Holdaway, S. (1997a). 'Constructing and Sustaining "Race" within the Police Workforce.' The British Journal of Sociology 48(1): 19-34.

Holdaway, S. (1997b). 'Responding to Racialised Divisions within the Workforce-the Experience of Black and Asian Police Officers in England.' Ethnic and Racial Studies 20(1): 69-90.

Holdaway, S. (2004). 'The Development of Black Police Associations: Changing Articulations of Race within the Police.' British Journal of Criminology 44(6): 854-865.

Holdaway, S. (2009). Black Police Associations: An Analysis of Race and Ethnicity within Constabularies. Oxford: Oxford University Press.

Holdaway, S. and Barron, A.-M. (1997). Resigners? The Experience of Black and Asian Police Officers. Basingstoke: Macmillan.

Home Office. (1990). Ethnic minority recruitment into the police service. 33/1990, Race, Policy.

House of Commons: Home Affairs Select Committee. (2013). Leadership and Standards in the Police. London: The Stationary Office.

Jenkins, R. (1996). Social Identity. London: Routledge.

Jenkins, R. (1997). Rethinking Ethnicity: Arguments and Explorations. London: Sage.

Manning, P. (2011). Democratic Policing in a Changing World. London: Paradigm Publishers.

Mundy, G., Russell, J. and Tuffin, R. (1999). Career Progression of Ethnic Minority Police Officers. London: Home Office. 
Office of National Statistics. (2014). Tables for 'Police Workforce, England and Wales, 31 March 2014.' https://www.gov.uk/government/statistics/tables-forpolice-workforce-england-and-wales-31-march-2014 (accessed 29 December 2014).

Phillips, C. (2005). 'Facing Inwards and Outwards?'.' Criminal Justice 5(4): 357-377.

Sansone, L. (2003). Blackness Without Ethnicity. Basingstoke: Palgrave Macmillan.

Sir William Macpherson of Cluny. (1999). The Stephen Lawrence Inquiry: Report of an Inquiry by Sir William Macpherson of Cluny. London: HMSO.

Smith, G., Harry, H.-J. and Chris, R. (2012). Disproportionality in Police Professional Standards, http://www.gmp.police.uk/ mainsite/pages/2073C1C52A9FABB880257A800044A656. htm (accessed 29 December 2014).
Stone, V. and Tuffin, R. (2000). Attitudes of People from Minority Ethnic Communities Towards a Career in the Police Service. London: Home Office.

The Policy Exchange. (2014). A Portrait of Mordern Britain. London: The Policy Exchange.

Williams, R. (2014). 'Police officer Carol Howard v the Met: 'I was absolutely humiliated'.' http://tinyurl.com/ q6m8u68.

Wilson, D., Holdaway, S. and Spencer, C. (1984). 'Black Police in the United Kingdom.' Policing 1(1): 20-30.

Wright, S. (2014). 'Yard corruption probe files destroyed in 2 days': Fury at 'mass shredding' of documents linked to Lawrence. http://tinyurl.com/qb3oasm. 